\title{
PELAKSANAAN PEMBELAJARAN BAHASA MELAYU DI SD AMANASAK KABUPATEN MUANG PATTANI THAILAND SELATAN
}

\author{
THE IMPLEMENTATION OF TEACHING MALAY LANGUAGE \\ AT AMANASAK PRIMARY SCHOOL, MUENG DISTRICT OF PATTANI, SOUTH THAILAND
}

\author{
Hasuenah Dumeedae, Haryadi \\ Pattani Thailand, Universitas Negeri Yogyakarta \\ hdumeedae@gmail.com,prof_haryadi@yahoo.co.id
}

\begin{abstract}
Abstrak
Penelitian ini bertujuan untuk mengungkap pelaksanaan proses pembelajaran bahasa Melayu di SD Amanasak Kabupaten Muang Pattani Thailand Selatan, meliputi pendekatan, metode, strategi teknik dan media pembelajaran, interaksi guru dan siswa, serta peran guru, siswa, dan materi. Penelitian ini menggunakan metode penelitian kualitatif. Subjek adalah guru, para siswa dan wakil kepala sekolah, objek adalah pelaksanaan pembelajaran bahasa Melayu di lembaga tersebut. Teknik pengumpulan data adalah observasi berpartisipasi, wawancara, dan studi dokumentasi. Hasil penelitian ini menunjukkan bahwa pendekatan, metode, strategi dan teknik pembelajaran yang digunakan cukup membuat siswa antusias untuk mempelajari bahasa Melayu. Media pembelajaran yang digunakan dalam laboratorium telah digunakan dengan maksimal, namun tidak sering digunakan. Interaksi guru dan siswa berjalan dengan baik, meskipun belum seluruhnya menggunakan bahasa Melayu dan bahkan penggunaan bahasa Thai masih lebih banyak daripada bahasa Melayu. Guru telah menjalani tugasnya sebagai fasilitator, perencana, dan pengontrol dengan baik. Siswa telah diberi kesempatan untuk mencari sumber belajar tambahan, sementara materi yang ada cukup membuat siswa bersemangat mengikuti pembelajaran. Pengelolaan kelas dalam belajar mengajar sudah meningkatkan hasil pembelajaran dengan efektif, dan efisien. Evaluasi proses pelajaran menggunakan tes berbahasa dari membaca, berbicara, menyimak dan menulis. Alat evaluasi sudah sesuai dengan rencana pelaksanaan pembelajaran dan kemampuan siswa yang berhubungan dengan aspek kognitif, sosial, afektif, dan personal. Pengukur ini sudah mencakup materi dan keterampilan berbahasa siswa.
\end{abstract}

Kata kunci: bahasa Melayu, pelaksanaan pembelajaran

\begin{abstract}
This study was animed at revealing the implementation of the Malay teaching at Amanasak Primary School, Mueng District of Pattani, South of Thailand, including the teaching approach, method, strategies, technique and media, teacher-student interaction, and the role of the teachers, students, and materials.This study used the qualitative method. The subjects consisted of teachers, students, and the vice principal. The object was the implementation of teaching Malay language at the school. The data were collected through participant observation, interviews, and document study. The results of the research show that the teaching approach, method, strategies and technique used in the teaching process has made the students enthusiastic to learn Malay. The teaching media used in the language laboratory have been used optimally, but is not often to used. The teacher-student interaction the runs well, although not in the whole process Malay is used, and the use of Thai is still more dominant than that of Malay. The teachers have done their task well as facilitator, planner, and controller. The students are given chances to look for learning sources, while the materials have made them enthusiastic to follow the teaching learning activities. The classroom management in the teaching and learning has improved the learning outcomes with the purpose effectively and efficiently. The evaluation of the learning is using the type of tests from reading, listening, and writing. The evaluation too is in accordance with the lesson plan and the ability of the students related to the cognitive, social, affective, and personal aspects. This gauge includes the materials and skill of the students.
\end{abstract}

Keywords: Malay language, implementation of learning 


\section{Pendahuluan}

Bahasa Melayu merupakan salah satu bahasa dari sepuluh bahasa yang populer digunakan oleh orang seluruh dunia dan bahasa yang digunakan masyarakat Thailand Selatan. Bahasa ini memegang peranan yang sangat penting di era globalisasi dikarenakan bahasa Melayu merupakan bahasa sentral di Asia Tenggara. Bahasa ini digunakan dalam berbagai aktivitas internasional, misalnya dalam forum komunikasi, ekonomi, politik, dan sebagainya. Untuk itu, penguasaan bahasa Melayu suatu bangsa tidak dapat dihindarkan karena merupakan syarat utama agar mampu menjalin hubungan komunikasi di tingkat internasional, sehingga eksistensi bangsa tersebut diakui oleh bangsa-bangsa di Asia Tenggara secara internasional. Untuk mewujudkan hal tersebut, pembelajaran bahasa Melayu perlu dilakukan, baik secara formal maupun non formal.

Bahasa Melayu dianggap penting untuk pengembangan ilmu pengetahuan, teknologi dan seni, serta pembinaan hubungan dengan bangsa lain. Oleh karena itu, bahasa Melayu tergolong mata pelajaran yang harus dikuasai oleh siswa sekolah dasar di Thailand Selatan. Salah satu upaya pemerintah untuk meningkatkan kemampuan siswa dalam menguasai bahasa Melayu adalah memasukkan mata pelajaran bahasa Melayu menjadi salah satu mata pelajaran pilihan. Bahasa Melayu juga diajarkan di sekolah Tadika dan sekolah menengah agama Aliyah. Tujuan pemerintah adalah agar para siswa dan warganya menguasai bahasa Melayu.

Pembelajaran bahasa Melayu merupakan salah satu mata pelajaran tambahan dari kurikulum Islam di SD Amanasak Kabupaten Muang Pattani Thailand Selatan yang didirikan tahun 1989. Sekolah ini memiliki keunggulan tersendiri dalam sistem pembelajaran dibandingkan SD lain di Kabupaten Muang Pattani Thailand Selatan. Untuk meningkatkan kualitas pendidikan bahasa Asian, khususnya kemampuan berkomunikasi bahasa Melayu secara lisan dengan didukung argumentasi ilmiah, pada hari pendidikan internasional diselenggarakan lomba pidato, tes keterampilan berkomunikasi bahasa ASEAN (bahasa Melayu), dan debat bahasa Melayu antara SD swasta sedaerah Pattani. Keunggulan tersebut dapat dilihat dari prestasi yang dimiliki oleh sebagian siswa SD Amanasak dalam argumentasi ilmiah tersebut. Akan tetapi, secara umum rancangan pembelajaran dan pengajaran bahasa Melayu yang baik belum mendapat perhatian pemerintah. Dalam hal ini, siswa belum mampu berhasil secara keseluruhan, meskipun ada yang menjuarai lomba pidato, tes keterampilan berkomunikasi bahasa Asean (bahasa Melayu), dan debat bahasa Melayu. Hal tersebut dapat dilihat dari kurang aktifnya sebagian dari siswa yang tidak ada dasar bahasa Melayu dalam mengikuti proses pembelajaran di kelas, kurang aktif dalam mencari sumber belajar tambahan selain dari buku paket, dan tidak mengerjakan pekerjaan rumah, baik tugas individu maupun tugas kelompok.

Berdasar data prasurvei tersebut, pelaksanaan pembelajaran bahasa Melayu mencakup pendekatan, metode, strategi dan teknik pembelajaran; media pembelajaran; interaksi guru-siswa; peran guru, siswa, materi pelajaran; pengelolaan kelas dan evaluasi dalam pembelajaran bahasa Melayu di kelas sebagian besar siswa beranggapan bahwa bahasa Melayu itu penting, tetapi mereka malu, dan takut berkomunikasi dengan bahasa Melayu. Perlu dilakukan studi kasus untuk mengetahui bagaimana pelaksanaan pembelajaran bahasa Melayu di SD Amanasak Kabupaten Muang Pattani Thailand Selatan.

Kajian pustaka yang dipaparkan beberapa konsep teoretis yang relevan sebagai landasan berpikir ataupun rasionalitas yang dapat mendukung pelaksanaan penelitian ini adalah teori yang terkaitannya dengan pembelajaran bahasa, menurut Abdul Chaer (2009, p.42) dikenal dua istilah pemerolehan bahasa (language acquisition) dan pembelajaran bahasa (language learning). Pemerolehan bahasa adalah proses ambang sadar (sub-consiousness) dan sifat alamiah yang dapat disamakan dengan proses yang dilalui seorang anak dalam menguasai bahasa pertamanya. Pemeroleh bahasa biasanya tidak menyadari bahwa ia sedang menggunakan bahasa tersebut untuk berkomunikasi. Sebaliknya, pembelajaran bahasa memiliki arti suatu proses sadar yang menghasilkan sistem atau pengetahuan bahasa. Dalam hal ini pembelajar bahasa menyadari adanya sistem bahasa (penguasaan gramatikal) tersebut sebagai hasil dari pembelajaran.

Faktor paling penting dalam mempelajari bahasa adalah pembelajaran itu sendiri. Untuk mencapai keberhasilan dalam belajar bahasa, siswa harus dapat mengarahkan dirinya pada keberhasilan dalam belajar ke arah positif. Untuk itulah dalam belajar bahasa 
asing, seseorang hendaknya memiliki motivasi yang kuat untuk dapat mencapai tingkat keberhasilan yang diharapkan, utamanya motivasi dari dalam diri siswa (instrinsic motivation), karena motivasi ini lebih banyak membantu dan berperan terhadap keberhasilan siswa. Hal ini disampaikan oleh Abraham Maslow (Brown, 2001, p.76) bahwa "intrinsic motivation is clearly superior to extrinsic". Kemudian pendapat ini didukung oleh Brown (2001, p.59) sendiri bahwa "The most powerful rewards are those that are intrinsically motivated within the learner. Because the behaviour stems from needs, wants, or desires within oneself, the behaviour itself is selfrewarding; therefore, no external administered reward is necessary."

Berikut ini pembelajaran bahasa Melayu sebagai bahasa asing, menurut Hamid, Z. (2006, p.168).

Apabila kita mengajar bahasa melayu sebagai bahasa asing fokusnya adalah kepada kehendak pelajar atau kelayan. Proses pengajaran yang memfokus kepada proses pemerkayaan bahasa akan memberikan tumpuan kepada proses menambahkan maklumat dan memperhalusi atau memantapkan lagi kemahiran berbahasa yang telah sedia dimiliki sejak kecil. Proses pengajaran yang memfokuskan kepada pembinaan tabiat berbahasa seharusnya memberikan keterampilan baru dalam bahasa kedua.

Pernyataan tersebut menjelaskan pembelajaran bahasa Melayu sebagai bahasa asing berpusat pada siswa yaitu berorientasi pada penguasaan kosakata, memperhalus bahasa serta meningkatkan keterampilan berbahasa yang sudah dimiliki siswa. Proses pembelajaran juga memfokuskan pada karakter berbahasa yang seharusnya memberikan keterampilan baru dalam menggunakan bahasa Melayu sebagai bahasa kedua.

Berdasarkan pandangan ini, bahasa Melayu merupakan alat untuk mengungkapkan gagasan, pikiran, pendapat, dan perasaan, baik secara lisan maupun secara tertulis. Bahasa Melayu di SD Thailand Selatan adalah alat untuk menyerap dan menyampaian ilmu agama, pengetahuan, dan seni budaya. Bahasa Melayu juga memiliki peranan yang sangat penting dalam pembinaan hubungan antara bangsa Thai dengan bangsa-bangsa lain seperti dalam bidang sosial, politik, ekonomi, dan perdagangan. Dapat dikatakan bahwa bahasa Mela- yu sebagai alat untuk mempercepat laju pembangunan Negara dan Bangsa Thai.

Sesuai dengan pengertian bahwa hasil belajar dari proses belajar mengajar adalah perubahan dalam tingkah laku, maka dalam pembelajaran bahasa hasil tersebut adalah siswa dapat berkomunikasi menggunakan bahasa tersebut. Untuk mencapai tujuan tersebut diperlukan guru bahasa Melayu di SD yang baik dengan karakteristik: mempunyai kompetensi memimpin; mencintai bahasa Melayu; berfikir kritis; gigih dalam meningkatkan diri; dapat menempatkan diri; siap kerja keras; mampu beradaptasi; bersikap profesional; dan mempunyai perasaan cinta terhadap pekerjaan (Brown, 2001, p.429)

Pendapat senada dikemukakan oleh Doyle (Hopkins, 1993, p.99) yang menyatakan bahwa seorang guru akan dapat meningkatkan belajar siswa sesuai dengan beberapa cara, yaitu: aktif dalam perencanaan dan pengorganisasian pembelajaran; menjelaskan pada siswa apa yang akan mereka pelajari; memberikan kesempatan kepada siswa untuk berlatih secara terbimbing; memonitor kemajuan siswa; memberikan umpah balik; dan membantu siswa untuk memahami dan menyelesaikan tugas dalam pembelajaran.

Berdasarkan uraian di atas, dapat disimpulkan bahwa pembelajaran bahasa Melayu di SD yang efektif adalah pembelajaran yang dapat meningkatkan kemampuan siswa dalam berbahasa Melayu menyangkut empat keterampilan, yakni speaking, reading, listening, dan writing. Sementara itu, perilaku guru yang efektif memungkinkan terciptanya pembelajaran bahasa Melayu yang efektif pula yang pada akhirnya menghasilkan siswa yang dapat menemukan cara belajar mereka sendiri, kreatif, dan mampu menggunakan bahasa Melayu di dalam maupun di luar kelas.

Dilihat dari pendekatannya, pembelajaran terdapat dua jenis pendekatan, yaitu: (1) pendekatan pembelajaran yang berorientasi atau berpusat pada siswa (student centered approach) dan (2) pendekatan pembelajaran yang berorientasi atau berpusat pada guru (teacher centered approach). Pendekatan, metode, strategi dan teknik pembelajaran bahasa Melayu merupakan istilah yang sering dicampuradukkan pengertian atau pemakaiannya. Brown (2001, p.16) menyatakan bahwa "approach : Theoretically well-informed positions and beliefs about the nature of language, 
the nature of language learning, and the applicability of both to pedagogical setting".

Pendekatan mencakup teori tentang keaslian bahasa yang terdiri dari sejumlah keaslian kecakapan bahasa dan sejumlah unitunit dasar, struktur bahasa, serta teori keaslian pembelajaran bahasa dari sejumlah proses kognitif dan psikolingguistik yang terlibat dalam pembelajaran bahasa, dan sejumlah kondisi yang menyebabkan berhasilnya penggunaan proses tersebut. Senada dengan itu, Richards \& Rodgers (1995, p.15) mengemukakan bahwa'...an approach is a set of correlative assumptions dealing with the nature of language teaching and learning”. Dengan demikian, dapatlah dikatakan bahwa pendekatan adalah serangkaian asumsi tentang sifat dan hakekat bahasa, pengajaran bahasa serta belajar bahasa.

Sementara itu, metode merupakan rencana menyeluruh mengenai penyajian materi pelajaran bahasa sesuai dengan pendapat Richards \& Rodgers (1995, p.15), bahwa "... method is an overall plan for the orderly presentation of language material, no part of which contradicts, and all of which in besed upon, the selected approach". Pendekatan menduduki posisi teoretis yang diterjemahkan ke dalam metode-metode yang selanjutnya dilaksanakan lewat teknik-teknik yang sesuai. Berikut pendekatan dan metode pengajaran bahasa yang dapat diterapkan dalam proses pembelajaran bahasa menurut Brown (2001, p.18) adalah (1) metode pembelajaran tata bahasa disertai terjemahan (the grammar-translation method), (2) metode bicara dalam bahasa target (The direct method), (3) metode dengar-ucap (the audiolingual method), dan (4) pendekatan komunikatif (communicative approach).

Dari pendekatan dan metode pembelajaran yang telah ditetapkan selanjutnya diturunkan ke dalam strategi pembelajaran. Proses pembelajaran bahasa Melayu merupakan interaksi yang dilakukan guru dengan siswa dalam suatu situasi pendidikan dan pengajaran untuk mewujudkan tujuan yang telah ditetapkan. Bentuk interaksi menghendaki adanya pertimbangan yang kuat atas keunikan dan keragaman siswa. Hal ini menunjukan betapa pentingnya keterampilan guru menyampaikan pesan, dan keterampilan menggunakan berbagai metode mengajar secara bervariasi.

Oemar Hamalik (2011, pp.131-133) menyebutkan paling tidak ada 4 strategi pem- belajaran yang pantas disajikan dan diketahui oleh guru/calon guru, ialah: a. Pembelajaran penerimaan (reception learning). b. Pembelajaran penemuan (discovery learning). c. Pembelajaran penguasaan (mastery learning). $\mathrm{d}$. Pembelajaran terpadu (unit learning). Sementara itu, Rebecca L. Oxford (1990, p.1) memberikan definisi tentang strategi pembelajaran bahasa. Menurutnya, "Learning strategies are steps taken by students to enhance their own learning. Strategies are especially important for language learning, because they are a tools for active, self-directive involvement, which is essential for developing communicative competence." Artinya strategi belajar adalah langkah-langkah yang diperlukan para siswa untuk meningkatkan belajarnya. Strategi tersebut secara khusus penting untuk belajar bahasa sebagai alat untuk membuat para siswa menjadi aktif dan terlibat langsung. Hal ini merupakan esensi pengembangan kompetensi komunikatif. Hasil penelitian Lamijan Hadi Susarno (2010, p.7), dapat kesimpulan bahwa yang perlu dipertimbangkan dari faktor siswa di dalam memilih strategi pembelajaran tersebut, antara lain siswa sebagai pribadi tersendiri memiliki perbedaan-perbedaan dari siswa lain dan jumlah siswa yang mengikuti pelajaran.

Selanjutnya teknik pembelajaran merupakan cara guru menyampaikan bahan ajar yang telah disusun (dalam metode), berdasarkan pendekatan yang dianut. Teknik yang digunakan oleh guru bergantung pada kemampuan guru itu mencari akal atau siasat agar proses belajar mengajar dapat berjalan lancar dan berhasil dengan baik. Dalam menentukan teknik pembelajaran bahasa Melayu ini, guru perlu mempertimbangkan situasi kelas, lingkungan, kondisi siswa, sifat-sifat siswa, dan kondisi-kondisi yang lain. Dengan demikian, teknik pembelajaran yang digunakan oleh guru dapat bervariasi sekali. Untuk metode yang sama dapat digunakan teknik pembelajaran yang berbeda-beda, bergantung pada berbagai faktor tersebut.

Arief S. Sadiman (2011, p.7) menjelaskan media adalah segala sesuatu yang dapat digunakan untuk menyalurkan pesan dari pengirim ke penerima, sehingga dapat merangsang pikiran, perasaan, dan minat serta perhatian siswa sedemikian rupa sehingga proses belajar dapat terjadi. Relevan dengan pendapat di atas Yusufhadi Miarso (2000, p.6) mengertikan media sebagai jenis komponen dalam 
lingkungan siswa yang dapat merangsang mereka untuk belara.

Dilihat dari segi manfaat media pembelajaran, Nana Sudjana \& Ahmad Rivai (1997, p.2) memberikan gambaran sebagai berikut. a) Pengajaran akan lebih menarik perhatian siswa, sehingga dapat menumbuhkan motivasi belajar; b) Bahan pengajaran akan lebih jelas maknanya, sehingga dapat lebih difahami oleh para siswa dan memungkinkan siswa menguasai tujuan pengajaran dengan lebih baik. c) Metode mengajar akan lebih bervariasi, tidak semata-mata komunikasi verbal melalui penuturan kata-kata oleh guru, sehingga siswa tidak bosan dan guru tidak kehabisan tenaga; d) Siswa lebih banyak melakukan kegiatan belajar.

Dari uraian di atas menjelaskan bahwa nilai dan manfaat media pembelajaran bahasa Melayu sangat besar bagi siswa. Penggunaan media dapat merangsang siswa dalam proses pembelajaran. Siswa lebih tertarik dan mudah memahami bahan-bahan pelajaran yang diberikan melalui dibandingkan dengan bahan-bahan pelajaran yang disampaikan secara verbal tanpa bantuan media.

Brown (2001, p.165) menyatakan bahwa "Interaction is an important word for language teachers. Interaction is the collaborative exchange of thought, feeling, or ideas between two or more people, resulting in a reciprocal effect on each other". Artinya, interaksi merupakan kata yang sangat penting bagi guru bahasa. Interaksi adalah pertukaran pemikiran, perasaan, atau ide antara dua orang atau lebih yang menghasilkan pengaruh di antara mereka. Lebih lanjut Brown (2001, p.165) mengatakan:

Theories of communicative competence emphasize the importance of interaction as human beings use language in various contexts to 'negotiate' meaning, or simply stated to get an idea out of person's head and into the head of another person and vice versa. In the era of communicative language teaching, interaction is, in fact, the heart of communication, it is what communication is all about.

Teori kemampuan berbahasa menekankan pada pentingnya interaksi manusia menggunakan bahasa dalam berbagai konteks untuk menemukan makna, menyatakan sesuatu, atau mendapatkan ide yang muncul dari seseorang kepada orang lain atau sebaliknya.
Dalam era pengajaran bahasa yang komunikatif, interaksi merupakan inti dari komunikasi apapun jenis komunikasinya. Lebih lanjutnya, Arends (1997, p.17) menyatakan interaksi guru-siswa terjadi di dalam kelas, karena itu dia menyatakan "classroom can be viewed as ecological systems in which inhibitants interact within a specific environment to complete valued tasks". Dikatakan bahwa kelas dipandang sebagai sistem ekologi di mana di dalamnya terjadi interaksi dalam lingkungan yang khusus untuk melakukan tugas yang bermakna.

Untuk memandang bagaimana pembelajaran guru terjadi dalam praktik seharihari, Knight (Elena 2009, p.3) berpendapat bahwa this study argues that spontaneous learning develops from multiple sources and in multiple contexts through interaction within communities of practice. pembelajaran spontan berkembang dari banyak sumber dan dalam banyak konteks melalui interaksi dalam komunitas-komunitas praktek. Evertson (1984, pp.153-156) menambahkan beberapa hal yang perlu diperhatikan dalam mendiagnosa penyebab terjadinya masalah di kelas ketika pembelajaran berlangsung, antara lain: a) mengevaluasi kembali manajemen kelas; b) mereview aturan dan prosedur dalam mengatur siswa; c) mereview prosedur akuntabilitas pokok; d) mendata konsekuensi perilaku yang baik dan tidak baik; e) mempertimbangkan dan mencegah terjadinya perilaku yang tidak baik di awal pembelajaran agar tidak berkembang menjadi besar ketika pembelajaran berlangsung; f) mempertimbangkan cara-cara yang dapat meningkatkan kualitas pembelajaran dan interaksi guru-siswa di kelas.

Guru memiliki peran sangat penting dalam merangsang munculnya keterlibatan siswa dalam situasi pembelajaran. Peranan guru tersebut adalah fasilitator dari proses komunikasi, partisipan (sebagai teman, dan bahkan orang tua), figure otoritas, pemimpin, direktur, manajer, konselor, guide, controller, dan sebagai sumber (Brown, 2001, pp.167-168). Guru sebagai fasilitator sangat diharapkan memiliki kualitas dan kompetensi. Hal tersebut seperti dikemukakan Robinnet (Finocchioro, 1981, p.57) sebagai berikut.

Some language teachers seem to be neither enthusiastic about the language they are teaching nor about their student' qualities like patience, tolerance, sensitivity, and warmth are innate. They can be nurtured, developed, brought, to 
the surface even created, if teachers are really interested in their students if they really want students to learn, if they are willing to try everything in their power tohelp their students.

Maksudnya adalah bahwa seorang guru bahasa harus antusias baik terhadap bahasa yang sedang diajarkan atau kepada siswa, kualitas guru yang meliputi kesabaran, toleransi, kepekaan dan kehangatan sangat penting. Perasaan tersebut dapat dikembangkan, dimunculkan bahkan diciptakan jika guru benarbenar tertarik atau menginginkan siswa mereka ingin belajar, dan jika guru benar-benar berkeinginan untuk mencurahkan segala kemampuannya untuk membantu siswanya. Pendapat senada dikemukakan Khine (2005, p.63) bahwa "effective teachers are teachers who promote student learning that enhance their cognitive, social, affective and personal development." yang berarti guru yang efektif adalah guru yang dapat mengembangkan kemampuan kognitif, sosial, afektif dan kemampuan personal siswa.

Peran siswa seperti yang dikemukakan oleh Johnson dan Paulston (Richads \& Rodgers, 1995, p.23) adalah:

1) Learners plan their own learning program and thus ultimately assume responsibility for what they do in the classroom; 2) Learners monitor and evaluate their own progress;3) Learners are members of a group and learn by interacting with others.;4) Learners tutor other learners.; 5) Learners learn from the teacher, from other students, and from other teaching sources.

Proses belajar memang memerlukan adanya keterlibatan siswa selama proses pembelajaran berlangsung baik berupa interaksi guru ataupun dengan siswa lainnya. Pembelajaran bahasa Melayu juga perlu melibatkan siswa untuk ikut berperan aktif dalam proses pembelajaran. Makin aktif siswa dalam belajar maka semakin aktif pula proses pembelajaran berlangsung, karena siswa menjadi aktif terlibat di dalamnya. Christopher (1995, p.1) menjelaskan "one way to boost learning is to combine a lecture with opportunities for students to reflect on and use the materiall". Untuk meningkatkan pembelajaran antara guru dan siswa harus merefleksikan materi yang telah dipelajari. Lebih lanjut Christopher (1995, p.2) menjelaskan:
Characteristics of active learning: Students are involved in more than listening; students are engaged in activities (reading, discussing, writing); less emphasis is placed on transmitting information and more on developing students' skills; students are involved in higher-thinking (analysis, synthesis, evaluation); students apply content and learn by doing; and emphasis is placed on students' exploration of their own attitudes and values.

Pembelajaran aktif adalah apabila siswa ikut terlibat dalam proses pembelajaran yang lebih dari sekedar mendengarkan; siswa terlibat dalam kegiatan-kegiatan pembelajaran seperti membaca, diskusi, menulis; tidak terlalu menekankan pada pemindahan informasi, tapi lebih pada pengembangan keterampilan siswa; siswa terlibat dalam pemikiran tingkat tinggi seperti analisis, sintesis, dan evaluasi; siswa menerapkan isi dan belajar dengan melakukan; dan penekanan ditijukan pada eksplorasi siswa terhadap sikap dan nilai-nilai mereka sendiri.

Peran materi pembelajaran menurut Richards \& Rodgers (1995, p.25) adalah:

The role of instructional materials within a method or instructional systems will reflect decisions concerning the primary goal of materials (e.g., to present content, to practice content, to facilitate communication between learners, or to enable learners to practice content without the teacher's help), the form of materials (e.g., textbook, audiovisuals, computer software), the relation of materials to other sources of input (i.e., whether tey serve as the major source of input or only as a minor component of it), and the abilities of teachers (e.g., their competence in the languge or degree of training and experience).

Peran dari materi pembelajaran di dalam sebuah metode atau sistem pembelajaran akan merefleksikan empat hal pokok yang terkait dengan: 1) tujuan utama bahan/materi pembelajaran (misalnya untuk menyajikan isinya, untuk mempraktikkan isinya, untuk memfasilitasi komunikasi antara siswa, atau untuk memungkinkan siswa mempraktikkan isinya tanpa bantuan guru), 2) bentuk bahan/materi pembelajaran (seperti buku teks, audio visual, software komputer), 3) hubungan bahan/materi pembelajaran dengan sumber-sumber balajar 
lainnya (misalnya apakah materi itu berpotensi sebagai sumber utama atau hanya sebagai kompenen minor saja), dan 4) kemampuankemampuan guru (seperti kompetensi mereka dalam bahasa atau tingkat pelatihan dan pengalaman).

Syaiful Bahri Djamarah dan Aswan Zain (2010, p.174) mengatakan bahwa pengelolaan kelas adalah salah satu tugas guru yang tidak pernah ditinggalkan. Guru selalu mengelola kelas ketika dia melaksanakan tugasnya. Pengelolaan kelas dimaksudkan untuk menciptakan lingkungan belajar yang kondusif bagi anak didik sehingga tercapai tujuan pengajaran secara efektif dan efisian.

Proses pembelajaran bahasa Melayu perlu ada evaluasi pengajaran Oemar Hamalik (2011, p.171) Mengatakan bahwa evaluasi pembelajaran adalah evaluasi terhadap proses belajar mengajar. Secara sistematik, evaluasi pembelajaran diarahkan pada komponen-komponen sistem pembelajaran, yang mencakup komponen input, yakni perilaku awal (entry behavior) siswa, komponen input instrumental yakni kemampuan profesional guru/tenaga, kependidikan, komponen kurikulum (program studi, metode, media), komponen administratif (alat, waktu, dana); komponen proses ialah prosedur pelaksanaan pembelajaran; komponen output ialah hasil pembelajaran yang menandai ketercapaian penilaian tujuan pembelajaran.

Rumusan masalah penelitian ini yaitu: Bagaimanakah proses pelaksanaan pembelajaran bahasa Melayu di SD Amanasak Kabupaten Muang Pattani Thailand Selatan. Tujuan yang dicapai dalam penelitian ini untuk mendeskripsikan proses pelaksanaan pembelajaran bahasa Melayu di SD tersebut.

\section{Metode}

\section{Jenis Penelitian}

Berdasarkan fokus penelitian tersebut, pendekatan penelitian yang tepat untuk mengungkap data adalah dengan menggunakan pendekatan kualitatif. Pendekatan ini digunakan agar diperoleh data yang orisinil yang akhirnya dapat diperoleh pemahaman dan makna data yang relative mendalam tentang fenomena yang diperoleh di lapangan.

\section{Tempat dan Waktu Penelitian}

Penelitian ini berlangsung selama 11 bulan, yaitu sejak bulan Juli tahun 2012 sam- pai bulan Mei tahun 2013. Penelitian ini berlokasi di SD Amanasak Kabupaten Muang Pattani Thailand Selatan, khususnya pada kelas bahasa Melayu IV, V, dan VI.

\section{Subjek dan Objek Penelitian}

Subjek dalam penelitian ini adalah para pelaku pembelajaran,yakni; (1) Wakil kepala sekolah selaku penanggung jawab bidang akademik di sekolah yang dipimpinnya. Pemilihan wakil kepala sekolah sebagai salah satu subjek penelitian merupakan rekomendasi dari kepala sekolah. (2) Guru, yaitu guru mengajar mata pelajaran bahasa Melayu tingkat SD dua orang. dan (3) Siswa, siswa yang dipilihnya 6 orang yaitu ketua kelas IV dua orang, kelas V dua orang, dan kelas VI dua orang. Objek dalam penelitian ini adalah pelaksanaan pembelajaran bahasa Melayu di SD Amanasak Kabupaten Muang Pattani Thailand Selatan.

Teknik dan Instrumen Pengumpulan Data

Metode pengumpulan data yang digunakan dalam penelitian ini adalah observasi, wawancara dan dokumentasi. Instrumen penelitian ini secara langsung terjun ke lapangan untuk mengumpulkan data dengan menggunakan beberapa instrumen tambahan yang lain. Sesuai dengan metode pengumpulan data, maka instrumen tambahan lain yang digunakan dalam penelitian ini adalah: lembar atau panduan pengamatan, pedoman wawancara (interview guide) dan dokumentasi yang relavan dengan masalah yang akan diteliti.

\section{Keabsahan Data}

Dalam penelitian ini, untuk menentukan keabsahan data peneliti menerapkan teknik trianggulasi, pengamatan terus-menerus, member chek, diskusi dengan teman sejawat, dependabilitas dan konfirmabilitas.

Teknik Analisis Data

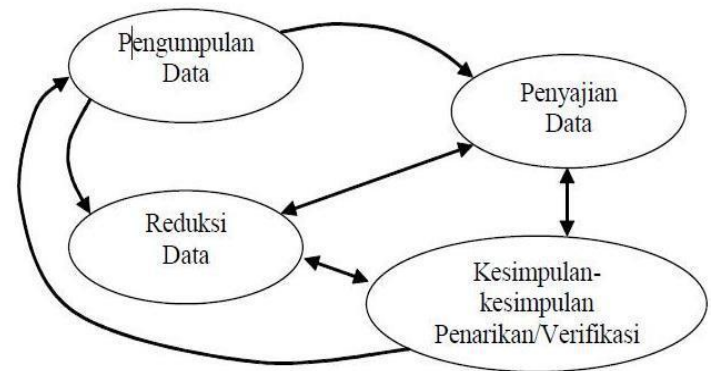

Gambar 1. Komponen-komponen Analisis Data Menurut Matthew B. Miles dan A. Michael Huberman (2009, p.20) 


\section{Hasil Penelitian dan Pembahasan}

Analisis Data

Pendekatan, Metode, Strategi dan Teknik Pembelajaran Bahasa

Proses pembelajaran bahasa Melayu, pendekatan, metode, strategi dan teknik merupakan satu hal yang sangat penting untuk diperhatikan oleh seorang guru bahasa Melayu agar proses pembelajaran tersebut dapat memperoleh hasil yang maksimal. Kesalahan memilih pendekatan, metode, strategi dan teknik akan berakibat pada kurang maksimal atau berhasilnya pembelajaran yang dilaksanakan. Sebaliknya, ketepatan memilih dan menggunakan pendekatan, metode, strategi dan teknik dalam pembelajaran bahasa Melayu akan berdampak pada lancar dan suksesnya pembelajaran yang dimaksud.

Berikut ini merupakan data yang dapat memberikan gambaran mengenai pendekatan, metode, strategi dan teknik yang digunakan dalam pembelajaran dalam pembelajaran bahasa Melayu di kelas IV, V, dan VI. Hal tersebut, dapat dilihat melalui data wawancara langsung guru bahasa Melayu dan siswa sebagai berikut.

Pendekatan/metode atau kegiatan yang dilakukan dalam pembelajaran bahasa Melayu, kami siswa hanya menerima apa yang diajarkan oleh guru. Biasanya, dalam pembelajaran bahasa Melayu kami mempelajari kosakata, tata bahasa, terjemahan, conversation dengan mendengarkan dan meniru apa yang diucapkan oleh guru, diskusi, individu dan kelompok dan mempelajari bahasa Melayu dengan cara peragaan peran di depan kelas. materi terjemahan memiliki porsi waktu yang lebih banyak jika dibandingkan dengan materi yang laiannya.

Pendekatan, metode pembelajaran bahasa Melayu di SD Amanasak yang digunakan oleh guru ada tiga pendekatan/metode adalah (a) metode pengajaran tata bahasa yang disertai dengan terjemahan (the grammar-translation method), (b) metode dengar-ucap (the audiolingual method), dan (c) pendekatan komunikatif (communicative approach). Tiga pendekatan/metode yang dilakukan berkaitan dengan kegiatan-kegiatan yang diajarkan oleh guru adalah kosakata, tata bahasa, kerja latihan, tanya jawab, terjemahan, conversation, guru bersama siswa membacakan suatu materi dengan suara nyaring, siswa meniru apa yang diucapkan oleh guru, diskusi, praktik mendengar dan membaca teks, ejaan, pidato, siswa mengajukan pemahaman mereka, guru kemudian menjelaskan, kolaborasi kegiatan di dalam kelas. Desain kegiatan diintegrasi sesuai materi luar dari pembelajaran yang ada. Dengan mempertimbangkan hal itu metode pembelajaran bahasa Melayu cocok untuk mengajarkan materi pembelajaran tertentu.

\section{Media Pembelajaran Bahasa Melayu}

Pesan yang akan dikomunikasikan adalah isi ajaran atau didikan yang ada dalam kurikulum. Media adalah segala alat fisik yang dapat menyajikan pesan serta merangsang siswa untuk belajar. Media-media tersebut adalah buku, dan kartun audio visual. Penggunaan media pembelajaran yang tepat dapat membantu mengatasi kekurangan, dan perbedaan yang ada dalam lingkungan belajar. Berikut ini merupakan data dan hasil pengamatan yang dapat memberikan gambaran mengenai media dan termasuk pada alat peraga pembelajaran bahasa Melayu.

Guru memperdalam pemahaman siswa terhadap bahan ajar atau sumber belajar dengan menggunakan media eksternal seperti CD atau perhatikan sesuatu di sekitar siswa. Guru bersama siswa membacakan suatu materi dengan suara nyaring, siswa praktik membaca, siswa mengajukan pemahaman mereka, guru lanjut menjelaskan, kolaborasi kegiatan di dalam kelas. Berikut ini, beberapa yang sempat peneliti amati antara lain: buku pegangan yang digunakan dalam pembelajaran bahasa Melayu adalah "Bahasa Melayu Tulisan Rumi Kelas IV, V ,VI Madrasah Amanasak Pattani" yang mengandung sumber belajar mengenai tata bahasa, bacaan, terjemahan, dan latihan-latihan, komputer, TV 29 inci, tape recoder, berguna untuk melatih kemampuan speaking, listening dan spelling siswa dari native speaker, kartu huruf, kartu kata, kartu kalimat, dan gambar.

Pembelajaran melalui media yang ada dalam laboratorium cukup membantu siswa dalam meningkatkan kemampuan berbahasa Melayu. Pembelajaran dengan menggunakan media juga membuat suasana belajar menjadi bergairah dan lebih variatif. Berdasarkan data cross check dengan siswa, pembelajaran melalui media yang ada dalam laboratorium bahasa di samping membuat suasana belajar menjadi lebih variatif juga cukup membantu para siswa dalam meningkatkan kemampuan speaking, listening dan spelling terutama dari kartun 
audio visual atau kaset yang diputarkan oleh guru.

\section{Interaksi Guru dan Siswa dalam Pembelajaran Bahasa Melayu}

Interaksi guru dan siswa di kelas bahasa Melayu, perilaku guru mempengaruhi perilaku belajar siswa yang pada akhirnya mempengaruhi prestasi belajar mereka. Guru yang memiliki kemampuan berbahasa Melayu yang baik akan memberi pengaruh positif terhadap kemampuan bahasa Melayu siswanya. Guru di sini menjadi figure sentral dan teladan yang baik bagi siswa. Sebaliknya, jika guru dalam interaksinya dengan siswa tidak menunjukkan sikap yang baik, tutur kata yang sopan, kemampuan komunikasi bahasa Melayu yang lancar, maka akan berpengaruh langsung pada sikap, tutur kata, dan kemampuan komunikasi bahasa Melayu siswa yang kurang baik dan maksimal.

Berikut ini merupakan data mengenai interaksi guru-siswa dalam proses pembelajaran bahasa Melayu di SD Amanasak.

Ibu guru mengatakan Assalamualaikum $\mathrm{Wr} \mathrm{Wt}$, dan memulai pembelajaran dengan membaca doa dengan menyuruh salah seorang siswa untuk memimpin doa dan surat Al-Fatihah. Setelah berdoa bersama guru membuka pembelajaran dengan beberapa sapaan dalam bahasa Melayu, seperti: "Selamat pagi!!!!! Apa kabar? Bolehkah Anda bercakap bahasa Melayu? Para siswa serentak menjawab dengan jawaban yang berbeda-beda, ada yang menjawab dengan baik dan ya, boleh cakap sedikit. Siswa meninjau materi dan berkomunikasi bersama guru dengan bahasa Melayu. Serentak guru menambah dari jawaban siswa dengan memotivasi siswa agar berani menjawab, tidak takut dengan jawaban yang salah.

Setelah penulisan sinopsis selesai, guru kemudian meminta kepada siswa untuk mengomentari isi kartun. Tampak semua siswa terdiam penuh konsentrasi menyiapkan argumentasinya. Ketika guru menyuruh salah seorang hari siswa untuk berkomentar, kelihatan siswa begitu malu-malu dan tidak berani. Ada seorang siswa mencoba untuk berkomentar, tetapi komentarnya tidak begitu lancar dan terbata-bata karena minimnya vocabulary. Salah seorang siswa tersebut mengatakan: 'Saya rasa sernak dengan kartun ini tapi....' maksud saya kurang bisa ditangkap maknanya karena ada beberapa kata yang tidak di pahami artinya. Akhirnya, guru membantu siswa tersebut untuk menjelaskan makna kartun tersebut dengan menggunakan bahasa Melayu dan bahasa Thai.

Berdasarkan data-data tersebut, dapat disimpulkan bahwa interaksi guru dan siswa di SD Amanasak cukup berjalan secara harmonis. Interaksi guru-siswa untuk mencapai tujuan dalam proses pembelajaran bahasa Melayu guru menggunakan cara penguatan dan motivasi siswa dalam proses pembelajaran di kelas seperti diskusi kelompok dan tukar pikiran ataupun di luar kelas siswa sangat menghormati para gurunya. Sebaliknya, guru sangat menyayangi siswanya. Sebagai indikator keharmonisan guru dan siswa dalam melakukan interaksi adalah ketika diskusi berlangsung guru memposisikan dirinya sebagai fasilitator dan pembimbing yang baik dalam mengarahkan jalannya diskusi. Interaksi yang harmonis ini merupakan model yang baik untuk membangun budaya belajar yang profesional. Salah satu kelemahan yang terlihat dari interaksi yang harmonis ini adalah tidak didukung oleh kemampuan komunikasi bahasa Melayu yang dimiliki oleh guru baik di dalam kelas maupun di luar kelas. Ketika proses pembelajaran bahasa Melayu di dalam kelas, guru lebih sering menggunakan bahasa Thai sebagai bahasa pengantarnya. Dalam membimbing siswa dalam percakapan bahasa Melayu dengan baik sering terdengar ungkapan bahasa Melayu yang dilengkapi bahasa Thai.

\section{Peran Guru, Siswa, dan Materi Pelajaran Bahasa Melayu}

Peran guru, siswa, dan materi pembelajaran bahasa Melayu di SD Amanasak dapat dilihat pada data-data berikut ini.

Guru bahasa Melayu masingmasing yang berwenang membuat RPP, dikumpulkan kepada bidang akademik untuk memvalidasi, kemudian digunakan dalam mengajar. Oleh karena itu, guru perlu merencanakan tanggung jawab mengajar mereka. Guru harus menganalisis RPP untuk menggunakan dalam belajar mengajar. Pertimbangan yang digunakan sebagai dasar pembuatan RPP adalah analisis kurikulum, materi, jadwal 
pengajaran, rencana pembelajaran. Hubungan RPP dengan siswa dan materi ajar yang pertimbangkan kondisi siswa harus konsisten dengan materi dan tujuan yang pertimbangkan student-centered learning dan evaluasi pretes, proses, dan postes dalam pembelajaran. Pembelajaran bahasa Melayu masih ada hambatan, guru mengatasi hambatan tersebut dengan menegaskan siswa untuk menggunakan bahasa Melayu dan berbicara dengan guru di dalam kelas.

Guru adalah contoh, harus berusaha menggunakan bahasa Melayu dengan tepat selama di dalam kelas dan bisa menjelaskan apa yang mereka tidak mengerti. Tugas saya sebagai seorang guru untuk membuat siswa menggunakan bahasa secara spontan dan membuat proses belajar berlangsung secara efisian dan lancar, siswa disuruh praktik menggunakan bahasa Melayu selama di sekolah, dan difokuskan pelatihan tanya jawab atau berbahasa Melayu.

Guru memberikan LKS kepada siswa untuk mewarnai gambar dan menulis warna gambar yang diwarnai, guru memposisikan diri sebagai fasilitator dan moderator bagi para siswa. Setelah waktu pembelajaran berakhir para siswa selesai dan mengumpulkan LKS pada guru. Guru menutup pertemuan dengan membaca Alhamdulillah dan diikuti oleh semua siswa, kemudian guru mengucapkan 'Aslamualaikum $W r$ Wt'. Siswa menjawab Wa'alaikumuslam $W r$ Wt. Tidak semua siswa mengumpulkan pekerjaan rumah. Ada dua siswa yang tidak mengumpulkan tugas pekerjaan rumahnya. Setelah ditanya oleh peneliti, di antaranya ada yang bilang lupa mengerjakannya, ada yang bilang tidak tahu jika ada pekerjaan rumah pada minggu lalu karena tidak hadir.

Selama siswa mengerjakan tugas, guru memposisikan diri sebagai fasilitator dan moderator bagi para siswa. Guru menutup pelajaran dengan berdoa bersama dan mengucapkan 'selamat tinggal dan jumpa minggu hadepan' dan dijawab serentak oleh para siswa 'Terima kasih cikgu!'. Beberapa menit kemudian guru meminta siswa untuk menulis sinopsis/meresensi dari kartun tersebut dalam bahasa Melayu untuk dikumpul- kan agar dapat diperiksa oleh guru di rumahnya dan dikembalikan minggu depan.

Guru dan siswa membaca bersama dan guru langsung bertanya tentang memahaman teks yang sudah dibaca. Guru memberi waktu 5 menit agar siswa membaca teks tersebut, sekalian membagi LKS jawaban soal dari teks.

Setelah kegiatan membaca dan menerjemahkan selesai kemudian dilanjutkan dengan berdiskusi. Guru membagi para siswa dalam lima kelompok. Selama diskusi berlangsung suasananya kurang berjalan dengan lancar dan hanya beberapa siswa saja yang dominan memberikan pendapatnya, sebagian besar dari para siswa masih malu-malu dan terbatabata dalam memberikan opininya karena kurang siap dan minimnya kosakata yang dimiliki siswa. Salah seorang siswa memberikan masukkan dalam bahasa Melayu: 'Sheikh Daud Bin Abdullah ialah seorang ulama dan pengarang terulung di Asia Tenggara'. Serentak para siswa yang lain mengatakan 'Sheikh Daud mempunyai semangat juangnya sangat tinggi, tidak pernah јети mencari ilmu'.

Peran siswa dalam kegiatan pembelajaran bahasa Melayu adalah belajar kosakata sebanyak mungkin dan siswa praktik, seperti berbicara dengan temanteman atau role-play. Ya, siswa bertanggung jawab kepada apa yang mereka kerjakan atau kegiatan-kegiatan pembelajaran dan siswa aktif dalam proses pembelajaran bahasa Melayu di kelas.

Berdasarkan data tersebut, guru sebagai pendidik adalah sentral bagi terciptanya siswa yang berkualitas. Dalam proses pembelajaran bahasa Melayu di kelas guru sangat diharapkan untuk memiliki kemampuan dalam menguasai mata pelajaran yang diampunya dan sekaligus mampu menjadi fasilitas, manajer, dan pemimpin bagi siswa. Guru sebagai contoh, harus berusaha menggunakan bahasa Melayu dengan tepat, selama di dalam kelas dan bisa menjelaskan apa yang mereka tidak mengerti. Guru menyuruh untuk siswa praktik menggunakan bahasa Melayu selama di sekolah, dengan berbicara bahasa Melayu bersamasama guru dan siswa, dan difokuskan pelatihan tanya jawab dalam berbahasa Melayu. Hal ini agar siswa menggunakan bahasa secara spon- 
tan dan membuat proses belajar berlangsung secara efisien dan lancar. Guru memaksa siswa tanya jawab dengan bahasa Melayu, walaupun tidak tepat dengan cara tata bahasa yang benar, tetapi siswa harus tetap berani.

Responden guru menambahkan bahwa guru dan siswa selalu berusaha mencari sumber belajar tambahan yang relevan untuk melengkapi buku pegangan yang ada, seperti dari buku-buku lain, majalah, surat kabar, dan internet. Antara buku pegangan dan sumber belajar tambahan yang relevan tersebut direncanakan sedemikian rupa agar menjadi materi belajar yang mudah dipahami oleh siswa.

Peran siswa dalam kegiatan pembelajaran bahasa Melayu adalah bertanggung jawab kepada apa yang mereka kerjakan atau kegiatan-kegiatan pelajaran. Siswa aktif dalam proses pembelajaran bahasa Melayu di kelas, sementara itu, belajar dan praktik kosakata sebanyak mungkin, seperti berbicara dengan teman-teman atau role-play, membaca suatu materi dengan suara nyaring dan menerjemahkannya dalam bahasa Thai. Sebagian kecil dari siswa dapat membaca dengan spelling dan pronouncing secara baik dan sebagian besar dari siswa membaca dengan spelling yang kurang baik. Dalam menerjemahkan bacaan tersebut, guru meminta siswa untuk mencari kata-kata yang sulit untuk diterjemahkan dengan membuka kamus yang telah disediakan. Siswa mengumpulkan LKS tersebut dengan segera. Kemudian pada akhir pelajaran siswa maju ke depan kelas untuk membaca dan menjawab apa yang dipahami mereka. Berikut ini adalah data mengenai peran materi.

Materi sebagai dasar pembuatan kegiatan pembelajaran bahasa Melayu (metode dan media) harus sesuai dengan kurikulum, kegiatan yang berfokus pada student-centered learning, media pembelajaran sesuai dengan materi konsisten dan modern.

Tujuan dan materi pembelajaran, serta dasar pengetahuan dan perhatian siswa adalah pertimbangan yang menjadi dasar pembuatan kegiatan pembelajaran bahasa Melayu. Menstimulasi memberikan perhatian dan siswa tidak merasa bosan dalam materi yang diajar, hal ini siswa dapat lebih mengingat dari pada meteri saja. Saya memperdalam pemahaman siswa terhadap bahan ajar atau sumber belajar agar siswa belajar pengetahuan luar kelas.
Materi dalam pembelajaran bahasa Melayu yang sesuai dengan kebutuhan siswa adalah materi yang memperhatikan siswa, baru dan yang paling modern sesuai dengan hidup nyata dan praktis. Ya, materi yang diberikan tepat dan sesuai dengan kemampauan siswa, karena materi jangan terlalu mudah dan sulit, semua siswa memahami bersama. Materi belajar yang efektif dan esensial untuk meningkatkan kemampuan berbahasa siswa adalah materi tidak sulit untuk memahami, dan belajar siswa. Guru bersama siswa membacakan suatu materi dengan suara nyaring, siswa praktik membaca, siswa mengajukan pemahaman mereka, guru lanjut menjelaskan, kolaborasi kegiatan di dalam kelas.

Berdasarkan data tersebut, materi dalam pembelajaran bahasa Melayu yang sesuai dengan kebutuhan dan kondisi siswa adalah materi yang memperhatikan siswa, baru, dan yang paling modern sesuai dengan kehidupan nyata dan praktis, materi jangan terlalu mudah dan sulit, sehingga semua siswa memahami bersama. Materi pelajaran yang dirancang sedemikian rupa yang bersumber dari guru, siswa, dan buku pegangan membuat siswa lebih antusias dan termotivasi dalam belajar. Penggunaan buku pegangan saja sebagai satu-satunya sumber belajar sangat membosankan siswa. Materi yang ada dalam buku pegangan hanya membahas seputar reading, writing, exercises, dan percakapan yang kadang tidak sesuai dengan kondisi siswa.

Peran guru, siswa dan materi dapat disimpulkan bahwa guru dan siswa interaksi dengan baik, berusaha berkomunikasikan dengan bahasa Melayu. Meskipun peran guru begitu sentral dalam terwujudnya proses pembelajaran yang baik, bukan berarti siswa tidak memiliki peran sama sekali dalam mendukung proses pembelajaran berlangsung. Idealnya siswa harus memiliki peran meskipun tidak sesentral peran yang dimiliki guru. Peran siswa dalam kegiatan pembelajaran bahasa Melayu adalah belajar kosakata sebanyak mungkin dan siswa mempraktikannya, seperti berbicara dengan teman-teman atau role-play. Siswa bertanggung jawab kepada apa yang mereka kerjakan atau kegiatan-kegiatan yang terkait dalam materi pembelajaran bahasa Melayu di kelas. Dalam perannya sebagai pengelola kelas, guru membentuk kelompok-kelompok diskusi untuk membahas materi pelajaran yang 
sudah dirancangnya terlebih dahulu. Di samping itu, guru memberikan beberapa tugas kelompok dan tugas individu untuk pekerjaan rumah bagi siswa. Hasil diskusi dan tugas kelompok serta tugas individu tersebut dievaluasi kembali hari berikutnya secara bersama-sama oleh guru dan siswa. Untuk menambah intensitas diskusi, siswa sering melakukan diskusi tambahan di luar jam belajar untuk lebih memahami dan menyegarkan kembali materi yang telah disampaikan oleh gurunya.

Faktor lain yang dapat meningkatkan keterlibatan siswa dalam proses pembelajaran bahasa Melayu di kelas yang paling penting adalah menggunakan bahasa Melayu dengan tepat dan bekerja sama pada tugas-tugas yang disuruh guru, seperti rajin belajar-belajar kosakata yang baru. Guru dalam hal ini harus tahu perbedaan individu siswa.

\section{Pengelolaan Kelas dalam Mengajar Bahasa Melayu}

Pengelolaan kelas adalah keterampilan guru untuk menciptakan dan memelihara kondisi belajar yang optimal dan mengembalikannya bila terjadi gangguan dalam proses belajar mengajar. Kegiatan-kegiatan tersebut untuk menciptakan dan mempertahankan kondisi yang optimal bagi terjadi proses belajar mengajar. Berdasarkan data-data yang dapat memberikan gambaran mengenai dalam kelas IV, V, dan VI di SD Amanasak, terdapat beberapa kegiatan dan cara pengelolaan kelas dalam mengajar bahasa Melayu berikut ini.

Pengelolaan kelas dengan kondisi siswa dalam proses pembelajaran bahasa Melayu adalah belajar bersama antara siswa pintar dan tidak pintar supaya bisa saling membantu. Dasar siswa adalah faktor-faktor yang dilakukan guru dalam pengelolaan kelas bahasa Melayu yaitu dasar pengetahuan dan kemampuan siswa saling membantu untuk mencapai kompetensi dasar. Hubungan antara guru-siswa penting dalam pengelolaan kelas baik, guru dapat mengakses layanan siswa dan ketelitian.

Ya, pernah merasa bosan saat pembelajaran bahasa Melayu berlangsung karena kadang-kadang ada jadwal belajar waktu siang dan tidak mengerti dalam materi yang diajar. Saya nyaman belajar dan dapat bergerak dengan leluasa. Meja dan kursi di kelas ini tidak nyaman untuk belajar karena ada paku di tengah meja. Saya tidak pernah suka merasa silau ketika berada di kelas tetapi, tidak suka mendengar kegaduhan atau kebisingan di dalam kelas ini karena rasa kesal.

Senang dengan pembelajaran bahasa Melayu karena, guru baik, memahami kami, saya dapat belajar kalimat bahasa Melayu yang tidak bisa membaca dan saya perhatian dengan benar-benar untuk ajari teman-teman yang tidak bisa berbahasa Melayu dan untuk digunakan dalam kehidupan sehari-hari. Saat pembelajaran bahasa Melayu berlangsung kadang-kadang merasa bosan ketika guru menjelaskan hal-hal yang sama dengan berulang-ulang, dan jika guru mengajar tetapi, teman-teman tidak perhatian dan bermain hal tersebut, membuat guru marah dan mengajar dengan tidak senang.

Berdasarkan data tersebut, terdapat beberapa kegiatan dan cara pengelolaan kelas dalam mengajar bahasa Melayu, diketahui bahwa kegiatan pelaksanaan pembelajaran sesuai dengan RPP, ruang kelas dan pencahayaan ditata sesuai dengan kondisi dan kebutuhan siswa, dan cara belajar mengajar menarik. Siswa mendapat perhatian dan aktif melakukan kegiatan mengisi LKS dalam keadaan proses pembelajaran dan merespon kegiatan apersepsi dengan antusias, tegas dan yakin berbahasa Melayu. Guru dalam menyampaikan materi langsung dengan berbahasa Melayu meskipun kadang-kadang menggunakan bahasa Thai sebagai bahasa pengantar.

Pengelolaan kelas adalah hubungan penting antara guru-siswa dalam pembelajaran bahasa Melayu. Pengetahuan dan kemampuan siswa saling membantu untuk mencapai kompetensi dasar adalah faktor-faktor penting yang digunakan guru dalam pengelolaan kelas bahasa Melayu. Data yang sama bahwa siswa bahagia dan senang, karena siswa suka pelajaran bahasa Melayu. Bahasa Melayu mudah mengerti dan dapat berbicara dan menulis, guru tidak memarahinya dan jarang disuruh kerja tugas-tugas. Guru baik, memahami kami, dan dapat belajar kalimat bahasa Melayu yang tidak bisa baca. Kami memperhatikan dengan benar-benar untuk mengajari teman-teman yang tidak bisa berbahasa Melayu dan agar digunakan dalam kehidupan sehari-hari. Bahasa Melayu adalah satu bahasa di Asean untuk kemudahan berbicara dan perjalanan keluar 
negeri seperti Malaysia, Indonesia, dan lainlain. Labih lanjut, siswa pernah merasa bosan karena, kadang-kadang jadwal belajar pada siang hari dan tidak mengerti materi yang diajarkan. Guru menjelaskan hal-hal yang sama dengan berulang-ulang, dan lebih bosan apabila guru mengajarkan tetapi teman-teman tidak perhatian dan bermain, hal ini membuat guru marahin dan mengajar dengan tidak senang.

Menurut guru bahasa Melayu, masalah manajemen adalah usaha untuk menciptakan dan mempertahankan kondisi sedemikian rupa sehingga proses belajar mengajar dapat berlangsung secara efektif dan efisien. Hal ini, dapat dilakukan dengan memberi penguatan, mengembangkan hubungan guru-siswa, membuat aturan kelompok yang produktif.

\section{Evaluasi Proses Pelajaran dalam Pembelajar- an Bahasa Melayu}

Evaluasi pembelajaran bahasa Melayu terhadap proses belajar mengajar dilakukan cara sistematik. Evaluasi pembelajaran diarahkan pada komponen-komponen sistem pembelajaran, yang mencakup komponen input, yakni perilaku awal (entry behavior) siswa, komponen input instrumental yakni kemampuan profesional guru, komponen proses ialah prosedur pelaksanaan pembelajaran, komponen output ialah hasil pembelajaran yang menandai ketercapaian penilaian tujuan pembelajaran.

Penilaian meliputi proses pengumpulan sejumlah bukti-bukti yang menunjukkan pencapaian hasil belajar siswa, pelaporan, dan penggunaan informasi tentang belajar siswa yang diperoleh melalui pengukuran untuk menganalisis dan menjelaskan kerja/prestasi siswa dalam mengerjakan tugas-tugas yang terkait dengan data dan informasi yang terkumpul, digunakan sebagai bukti ukuran keberhasilan pengajaran. Berdasarkan data wawancara dan pengamatan dalam evaluasi, peneliti dapat informasi bahwa dilihat pada hasil penelitian berikut ini.

Guru bahasa Melayu yang berwenang membuat RPP, dikumpulkan kepada bidang akademik untuk memvalidasi, kemudian digunakan dalam mengajar. Guru harus menganalisis RPP untuk menggunakan dalam belajar mengajar. Oleh karena itu, guru perlu merencanakan tanggung jawab mengajar mereka. Pertimbangan yang digunakan sebagai dasar pembuatan RPP adalah analisis kurikulum, materi, jadwal pengajaran, rencana pembelajaran. Hubungan RPP dengan siswa dan materi ajar yang pertimbangkan kondisi siswa harus konsisten dengan materi dan tujuan yang pertimbangkan student-centered learning dan evaluasi pretes, proses, dan postes dalam pembelajaran. Pembelajaran bahasa Melayu masih ada hambatan, guru mengatasi hambatan tersebut dengan menegaskan siswa untuk menggunakan bahasa Melayu dan berbicara dengan guru di dalam kelas.

mekanisme penilaian atau penskoran hasil belajar siswa diperoleh dengan mengukur/menilai keterampilan berbahasa dari membaca, berbicara, menyimak dan menulis. Diperkirakan KKM untuk mata pelajaran bahasa Melayu 60 persen. Penggunaan mekanisme penilaian tersebut karena evaluasi dengan tepat dan jelas. Akan tetapi, jenis penilaian pembelajaran bahasa Melayu yang dilaksanakan masih sedikit ada hambatan, karena tiap-tiap siswa mempunyai kemampuan memahami materi berbeda. Hal itu membuat setiap siswa perlu waktu untuk mempelajari yang berbeda-beda. Cara mengatasi hambatan tersebut yaitu memperbaiki kriteria evaluasi atau menambah waktu mengajar setiap peningkatan unit untuk siswa yang memahaminya relatif lambat. Tersedia lembar observasi perilaku siswa dalam mata pelajaran. Penilaian dari RPP, pengajaran dan kegiatan belajar, metode dan media pembelajaran, berkomunikasi bahasa Melayu dengan siswa di dalam kelas, tes ujian dan penilaian dari fakta-fakta yang benar dengan pemahaman siswa di kelas setiap pelajaran dan relatif dengan materi pelajaran.

Prosedur evaluasi dalam pembelajaran bahasa Melayu penilaian keterampilan siswa bisa berbagai cara. Keterampilan membaca bisa menilai dengan cara membaca teks. Keterampilan berbicara bisa menilai dengan cara wawancara atau berbicara sama teman-teman di kelas. Evaluasi dilakukan untuk menilai pengetahuan siswa dan menilai keterampilan menulis. Penilaian keterampilan siswa bisa dilakukan dengan menilai antara bab per bab dan bisa menilai pengetahuan siswa dengan ujian tengah dan akhir semester. Hal tersebut adalah teknik mengevaluasi proses pembelajaran bahasa Melayu yang digunakan agar sesuai antara evaluasi dengan materi pembelajaran bahasa Melayu, dan sesuai antara evaluasi dengan kemampuan siswa. Alat evaluasi 
yang digunakan sudah sesuai dengan RRP dan mencakup materi yang siswa sudah pelajari sehingga bisa menilai keterampilan siswa dari semua sisi.

Penilaian yang digunakan guru, berhubungan dengan aspek kognitif, sosial, afektif, dan personal, karena alat pengukur ini sudah mencakup materi dan keterampilan siswa. Waktu yang tepat untuk melakukan penilaian atau evaluasi kepada siswa ketika selesai matari per unit, oleh karena siswa sudah pelajari materi semua di antara unit per unit, guru perlu menguji, menilai pengetahuan siswa.

\section{Pembahasan}

Pendekatan, Metode, Strategi dan Teknik Pembelajaran Bahasa Melayu

Pendekatan, metode, strategi dan teknik yang dapat diterapkan dalam proses pembelajaran bahasa menurut Brown (2001, p.18) yaitu (1) metode pembelajaran tata bahasa disertai terjemahan (the grammar-translation method), (2) metode bicara dalam bahasa target (The direct method), (3) metode dengarucap (the audiolingual method), dan (4) pendekatan komunikatif (communicative approach). Penggunaan pendekatan/metode mengajar guru dipengaruhi oleh materi yang diajarkan. Ada materi yang cocok dengan metode diskusi dengan belajar kolompok dan ada juga materi yang cocok dengan tanya jawab.

Berdasarkan hasil penelitian yang ada di lapangan bahwa pendekatan, metode, strategi dan teknik yang digunakan dalam proses pembelajaran bahasa Melayu di SD Amanasak, yaitu: (a) pembelajaran conversation, (b) pembelajaran vocabulary dan translation, (c) pembelajaran reading, listening, dan understanding, (d) pembelajaran grammar, (e) pembelajaran reading dan translation teknik diskusi. Metode pengajaran tata bahasa disertai terjemahan (the grammar-translation method), metode dengar-ucap (the audiolingual method), dan pendekatan komunikatif (communicative approach). Pembahasan tentang masingmasing pendekatan/metode yang digunakan dalam pembelajaran bahasa Melayu di SD Amanasak Kabupaten Muang Pattani Thailand Selatan, sebagai berikut. Pendekatan tersebut, terkait dengan pendekatan/metode yang diterapkan oleh Brown adalah: (a) The grammar translation method (metode terjemahan-tata bahasa). Metode pengajaran tata bahasa diser- tai dengan terjemahan digunakan oleh guru, kerena metode ini dianggap paling relevan dengan kondisi siswa yang masih lemah dalam pemahamam grammar dan terjemahan. Untuk memberikan pemahaman terhadap grammar guru memilih materi-materi grammar yang sesuai dengan kurikulum yang ada di SD Amanasak, yaitu diambil dari buku pegangan untuk SD, yaitu Bahasa Melayu Tulisan Rumi Kelas 4 Madrasah Amanasak Pattani. (b) The audiolingual method (metode dengar-ucap). Metode ini ditekankan pada aktivitas mendengarkan, menirukan, dan melafalkan bunyibunyi bahasa Melayu. Guru menulis di atas papan tulis ungkapan-ungkapan yang sesuai dengan suatu konteks kemudian membacakannya dengan pronounciation yang baik. Selain itu, guru juga membacakan bacaan yang ada dalam buku pegangan dengan harapan siswa terjadi proses dialog dan diskusi tentang suatu masalah yang aktual di linkungan mereka. Guru juga meminta siswa membuat dialog sesuai dengan materi dalam buku paket dan kadang dialog bebas kemudian dipraktikkan di depan kelas oleh masing-masing kelompok. Metode audiolingual sering juga digunakan oleh guru ketika pembelajaran berlangsung di dalam ruangan laboratorium. Dalam hal ini, guru memperdengarkan vocabulary dan ungkapan-ungkapan berbahasa Melayu dari native speaker melalui tape recorder yang ditiru dan dilafalkan oleh siswa. Proses pembelajaran seperti ini bertujuan untuk melatih keterampilan listening, speaking dan spelling siswa. Selain itu, untuk membiasakan siswa dengan ungkapan-ungkapan berbahasa Melayu sehari-hari, guru selalu menggunakan sapaan rutin, misalnya "Selamat pagi." pada awal pelajaran jam pagi dan "Selamat ketemu lain kali" pada akhir jam pelajaran. Pembiasaan terhadap sapaan rutin ini menjadikan siswa terbiasa untuk menggunakannya. Dalam pengamatan peneliti di kelas, peneliti mendengar beberapa sapaan dari siswa, seperti: "Apa khabar?" dan dijawab oleh siswa lainnya, ada yang jawab dengan " Alhamdulillah baik". Ketika guru menyapa pada akhir pelajaran, mereka tidak hanya dapat merespon dengan "Terima kasih cikgu", Di lain kesempatan ketika guru mengakhiri pelajaran dengan mengatakan "selamat tinggal dan jumpa minggu hadepan”, siswa menjawab dengan "Ya, Cikgu!" c) Communicative approach (pendekatan komunikatif). Guru menggunakan beberapa teknik pembelajaran, yaitu diskusi dan conversation (per- 
cakapan). (1) diskusi: dalam kegiatan diskusi guru membagi siswa dalam beberapa kelompok (small group discussion). Setiap kelompok diberikan beberapa topik untuk didiskusikan. Berdasarkan keterangan dari guru bahasa Melayu, bahwa siswa dapat mendiskusikan tentang materi-materi yang ada dalam textbook seperti tentang Sheikh daut al-fatoni, Kebun buah-buahan, dan lain-lain hal sekitar siswa seperti warna, serta tentang isu-isu hangat dari sumber lain yang diketahui oleh siswa. (2) conversation: dalam kegiatan conversation siswa mempraktikkan teks-teks conversation yang tersedia dalam buku pegangan dan teksteks yang disusun sendiri oleh guru dan siswa. Kegiatan conversation bertujuan untuk membiasakan siswa agar memiliki kemampuan speaking yang baik.

\section{Media Pembelajaran Bahasa Melayu}

SD Amanasak telah memperankan sebuah pelajaran bahasa untuk mengefektifkan kegiatan pembelajaran bahasa Melayu. Guru sudah dapat menfasilitasi kegiatan yang dapat meningkatkan keterampilan listening, speaking, dan penguasaan tata bahasa. Pada saat meningkatkan ketiga jenis keterampilan tersebut, pengajaran tata bahasa misalnya, dilakukan dengan memutarkan $\mathrm{CD}$ pembelajaran yang berisi beberapa kartun audio visual tentang grammatical order yang dilengkapi buku-buku pelajaran grammar atau dengan memperdengarkan dialog yang terdapat di dalam CD bahasa Melayu Conversations yang mengandung berbagai percakapan, misalnya dua orang native speakers yang sedang berbelanja di pasar minggu. Media tersebut selain meningkatkan keterampilan listening juga dapat meningkatkan pemahaman dan penguasaan siswa terhadap materi tata bahasa. Untuk meningkatkan keterampilan speaking, tersedia beberapa CD percakapan yang mengajarkan language functions yang menjadi target pelajaran berbicara. Selain itu, tersedia juga beberapa kartun animation yang dapat diputar siswa dengan menggunakan DVD player. Kartun yang pernah diputar adalah kartun 'Upin Ipin'. Setelah selesai permutarannya, setiap siswa menceritakan sinopsis dan mereview dari kartun tersebut.

Dalam meningkatkan keterampilan listening siswa, selain menggunakan media CD yang disebutkan di atas guru juga memanfaatkan fasilitas laboratorium lainnya, seperti komputer untuk memanfaatkan materi perca- kapan dan lagu-lagu popular berbahasa Melayu. Lagu yang diputarkan adalah 'Anak Islam'. Laboratorium bahasa memiliki alat-alat sebagai berikut: televisi 29 inch. yang dilengkapi DVD player, tape recoder, komputer. Peralatan-peralatan tersebut dapat digunakan untuk mengajarkan keterampilan listening dan speaking serta untuk penyelenggaraan tes listening. Pengakuan dari Kepala Sekolah, ialah keberadaan laboratorium bahasa telah mengantarkan SD Amanasak siap mengoptimalkan kegiatan belajar bahasa Melayu. Data yang mutakhir yang dapat dilihat dari hasil laboratorium bahasa ini adalah juara lomba debat bahasa Melayu antara SD se-daerah dan terpilihnya guru dan siswa SD Amanasak untuk pertukaran siswa dengan Negera Malaysia.

\section{Interaksi Guru dan Siswa dalam Pembelajaran Bahasa Melayu}

Menurut Brown (2001, p.65), interaksi merupakan kata yang sangat penting bagi guru bahasa, karena interaksi adalah pertukaran pemikiran, perasaan, atau ide antara dua orang atau lebih yang menghasilkan pengaruh di antara mereka. Interaksi yang baik antara guru dan siswa dalam proses pembelajaran bahasa Melayu adalah interaksi yang di dalamnya terjadi pertukaran pemikiran, perasaan atau ide agar menghasilkan kolaborasi yang saling mengisi satu sama lain. Dalam konteks ini guru dan siswa merupakan sumber belajar.

Interaksi guru dan siswa di SD Amanasak sangat harmonis dalam arti sangat menghargai satu sama lain. Guru begitu sayang kepada siswanya dan begitu juga sebaliknya siswa menghormati gurunya. Kondisi yang harmonis ini terjadi karena guru dapat memposisikan dari sebagai teladan bagi siswanya. Indikator keharmonisan antara guru dan siswa dalam berinteraksi adalah guru menyapa siswa dengan tutur kata yang sopan, memotivasi siswa untuk terus belajar dengan giat, dan menjadi sumber belajar yang menyenangkan bagi mereka. Ketika guru mengucapkan salam siswa serentak menjawabnya, ketika siswa bertanya guru berusaha untuk menjawab dengan maksimal atau semampunya. Sikap guru yang menyenangkan ini dapat membuat siswa bersemangat untuk mengikuti proses pembelajaran dengan baik. Sebaliknya, guru yang menunjukan sikap kasar, otoriter, dan tidak menyenangkan akan membuat siswa menjadi takut, tidak percaya diri, dan tidak kreatif. 
Interaksi guru dan siswa yang paling menonjol dapat dilihat dari proses diskusi kelas. Guru memberikan kesempatan yang banyak bagi siswa untuk ikut aktif berbicara bahasa Melayu mengenai materi yang didiskusikan. Guru juga memberikan kebebasan kepada mereka untuk memilih materi apa saja yang ada dalam buku paket dan materi lepas lainnya. Dalam diskusi guru memposisikan dirinya sebagai fasilitator, moderator, pengontrol dan manajer kelas yang baik, bukan sebagai satu-satunya sumber pembejaran. Untuk mendukung proses diskusi guru membentuk beberapa kelompok diskusi (small class discuss) yang masing-masing kelompok terdiri dari empat sampai lima orang. Pembentukan kelompok diskusi bertujuan agar semua siswa dapat lebih aktif untuk berkomentar.

\section{Peran Guru, Siswa, dan Materi Pembelajaran Bahasa Melayu}

Guru pembelajaran bahasa Melayu di SD Amanasak memiliki peran untuk siswa agar menguasai bahasa Melayu. Peran guru antara lain seseorang pengajar mengelola kelas dengan baik agar suasana pembelajaran menjadi kondusif, memberikan pelajaran yang sesuai dengan kebutuhan siswa, dan berusaha mendapatkan sumber belajar tambahan dari berbagai sumber yang relevan dengan pembahasan atau kurikulum yang sudah dijadwalkan bersama. Sementara siswa memiliki peran mematuhi dan mengerjakan tugas dan kewajibannya, seperti menanggapi pertanyaan dari guru, melakukan diskusi kelas, melakukan percakapan bahasa Melayu di depan kelas, mencari sumber belajar tambahan, mengerjakan PR, ulangan, dan semester akhir. Pada hari-hari tertentu guru membawa bahan ajar yang difotokopi dari buku yang lain, majalah, dan dari internet. Untuk melengkapi bahan ajar guru juga mengintruksikan kepada siswanya untuk mencari sumber belajar tambahan. Di samping itu, guru sering menginstuksikan untuk mencari sumber belajar tambahan seperti buku, majalah, surat kabar, dan masalah-masalah realitas di masyarakat yang ditulis secara deskriptif. Adanya kombinasi dari ketiga sumber belajar dari guru, siswa, dan materi dapat memperkaya sumber belajar dan menjadikan suasana pembelajaran di dalam kelas lebih bervariasi. Dalam suasana tertentu, pemaparan sumber pelajar tambahan dari guru dan siswa dapat membuat suasana menjadi lebih hidup dan memberikan semangat baru kepada siswa.
Materi pembelajaran yang disampaikan oleh guru bahasa Melayu adalah buku ' $B a$ hasa Melayu Tulisan Rumi kelas IV, V, dan VI Madrasah Amanasak Pattani' penerbit Benhalabi Pres Pattani mengutamakan materi reading dan writing, sehingga menurut siswa materi ini sangat membosankan. Sangat sedikit kesempatan bagi siswa untuk mengembangkan keterampilan berbahasa yang lain, yaitu listening, dan speaking. Dengan demikian siswa tidak dapat mengembangkan kemampuan berkomunikasi menggunakan bahasa Melayu sebagai tujuan utama pembelajaran bahasa Melayu.

Bentuk pengorganisasian kelas yang dipakai oleh guru yakni secara klasikal atau individual. Dengan tugas tersebut siswa tidak dapat saling bertukar pikiran dengan teman lainnya. Siswa nampaknya sangat tertutup mengerjakan tugas secara sendiri-sendiri dan tidak kelihatan adanya kerja sama antara mereka. Kondisi seperti ini otomatis tidak memungkinkan adanya interaksi atau komunikasi menggunakan bahasa Melayu antara siswa.

\section{Pengelolaan Kelas dalam Mengajar Bahasa Melayu}

Syaiful Bahri Djamarah dan Aswan Zain (2010, p.174) mengatakan bahwa pengelolaan kelas adalah salah satu tugas guru yang tidak pernah ditinggalkan. Guru selalu mengelola kelas ketika dia melaksanakan tugasnya. Pengelolaan kelas dimaksudkan untuk menciptakan lingkungan belajar yang kondusif bagi anak didik sehingga tercapai tujuan pengajaran secara efektif dan efisian. Ketika kelas terganggu, guru berusaha mengembalikannya agar tidak menjadi penghalang bagi proses belajar mengajar.

Pengelolaan kelas dalam belajar mengajar bahasa Melayu di SD Amanasak masih ada hambatan walaupun kegiatan pelaksanaan pembelajaran sesuai dengan RPP. Ruang kelas dan pencahayaan ditata sesuai dengan kondisi dan kebutuhan siswa, dan cara belajar mengajar menarik. Siswa dapat perhatian dan aktif melakukan kegiatan mengisi LKS dalam keadaan proses pembelajaran dengan baik dan merespon kegiatan apersepsi dengan antusias, tegas dan yakin berbahasa Melayu. Guru menggunakan dua bahasa sebagai pengantar dalam menyampaikan materi pelajaran yaitu bahasa Melayu dan terkadang menggunakan bahasa Thai. Akan tetapi, di dalam kelas siswa dapat bergerak dengan leluasa dan nya- 
man, meskipun kadang-kadang merasa silau ketika berada di kelas. Merasa bosan ketika guru menjelaskan hal-hal yang sama dengan berulang-ulang, dan lebih bosan apabila guru mengajar tetapi teman-teman tidak memperhatikan dan bermain. Hal ini membuat guru marah dan mengajar dengan tidak senang. Jadwal belajar pada waktu siang hari pun salah satu masalah yang membuat kami bosan dan tidak mengerti materi yang diajarkan. Meja dan kursi di kelas ini ada yang tidak nyaman karena ada paku di tengah meja.

Secara keseluruhan guru dan siswa berusaha harmonis dalam kegiatan-kegiatan pembelajaran bahasa Melayu kesepakatan antara guru-siswa untuk menciptakan dan mempertahankan kondisi sedemikian rupa sehingga proses belajar mengajar dapat berlangsung dan tercapai tujuan pengajaran secara efektif dan efisien. Hal itu, dilakukan dengan memberi penguatan, mengembangkan hubungan gurusiswa, membuat aturan kelompok yang produktif.

\section{Evaluasi Proses Pelajaran dalam Pembelajar- an Bahasa Melayu}

Menurut Oemar Hamalik (2011, p.171) mengatakan bahwa evaluasi pembelajaran adalah evaluasi terhadap proses belajar mengajar. Untuk mengembangkan suatu program pendidikan, yang meliputi evaluasi proses pelajaran dalam pembelajaran bahasa Melayu itu penting dalam komponen output ialah hasil pembelajaran yang menandai ketercapaian penilaian tujuan pembelajaran.

Evaluasi proses pelajaran bahasa Melayu di SD Amanasak menggunakan mekanisme penilaian atau penskoran hasil belajar siswa dengan alat pengukur/menilai keterampilan berbahasa dari membaca, berbicara, menyimak dan menulis diperkirakan KKM untuk mata pelajaran bahasa Melayu 60 persen. Sementara itu, prosedur evaluasi dalam pembelajaran bahasa Melayu penilaian keterampilan siswa bisa berbagai cara. Keterampilan membaca bisa menilai dengan cara membaca teks. Keterampilan berbicara bisa menilai dengan cara wawancara atau berbicara sama teman-teman di kelas. Menilai pengetahuan siswa dan menilai keterampilan menulis. Penilaian keterampilan siswa bisa menilai antara bab per bab dan bisa menilai pengetahuan siswa dengan ujian tengah dan akhir semester. Hal tersebut adalah teknik mengevaluasi proses pembelajaran bahasa Melayu yang digunakan sesuai antara evaluasi dengan materi pembelajaran bahasa Melayu, dan sesuai antara evaluasi dengan kemampuan siswa, karena alat evaluasi yang digunakan sesuai dengan RRP dan mencakup materi yang siswa sudah pelajari dan bisa menilai keterampilan siswa semua sisi.

Wakil Kepala sekolah mengungkapkan bahwa strategi yang dilakukan agar pembelajaran bahasa Melayu di SD Amanasak lebih menarik dari pada SD yang lain, yaitu RPP yang pertimbangkan siswa dengan studentcentered learning, Digunakan berbagai media pembelajaran dengan pertimbangkan studentcentered learning.

Rencana pelaksanaan pembelajaran yang berpusat salah satu perangkat dari jenis pengukuran pengembangan pengetahuan siswa. Guru menggunakan jenis penilaian tersebut, karena evaluasi yang tepat dan jelas. Jenis penilaian yang digunakan guru, berhubungan dengan aspek kognitif, sosial, afektif, dan personal, karena alat pengukur ini sudah mencakup materi dan keterampilan siswa. Waktu yang tepat untuk melakukan penilaian atau evaluasi kepada siswa ketika selesai materi per unit, oleh karena, siswa sudah pelajari materi semua di antara unit per unit, guru perlu menguji, menilai pengetahuan siswa.

\section{Simpulan dan Saran}

Proses pelaksanaan pembelajaran bahasa Melayu di SD Amanasak Kabupaten Muang Pattani Thailand Selatan", dapat ditarik beberapa kesimpulan sebagai berikut.

Pendekatan, metode, strategi dan teknik pembelajaran yang diterapkan adalah: (a) the grammar translation method, (b) the audiolingual method dan (c) communicative approach (pendekatan komunikatif). Penggunaan tiga pendekatan/metode ini cukup membuat siswa antusias untuk mempelajari bahasa Melayu. Materi-materi grammar yang sesuai dengan kurikulum yang ada di SD Amanasak, yaitu buku pegangan untuk SD, "Bahasa Melayu Tulisan Rumi Kelas 4 Madrasah Amanasak Pattani". Metode yang digunakan untuk menggunakan bahasa sebagai alat komunikasi, menekankan ditekankan pada aktivitas mendengarkan, menirukan, dan melafalkan bunyibunyi bahasa Melayu. Metode audiolingual sering juga digunakan oleh guru ketika pembelajaran berlangsung di dalam ruangan laboratorium. Selaian itu diskusi dan conversation (percakapan). Sementara itu, media yang tersedia sudah digunakan sesuai materi. Media 
pembelajaran yang dimaksud antara lain: media pembelajaran dalam kelas berupa textbook, label tajuk, kartu huruf, dan kartu kata, media pembelajaran yang ada dalam laboratorium bahasa antara lain: berupa TV 29 inci, CD/DVD player, komputer, audio visual, multimidia, tape recoder, kamus, namun tidak sering digunakan.

Interaksi guru dan siswa dalam pembelajaran bahasa Melayu sudah berjalan dengan baik, harmonis, dialogis dan menyenangkan. Namun demikian, guru kurang maksimal menggunakan bahasa Melayu ketika berinteraksi dengan siswa. Kondisi ini menghambat keinginan siswa untuk dapat berbicara dalam bahasa Melayu. Peran guru dan materi pembelajaran (textbook) sebagai sumber belajar sangat dominan. Siswa belum begitu banyak berperan sebagai subjek belajar, sebagian besar siswa masih cenderung pasif. Materi pembelajaran masih kurang lengkap, seperti buku paket, dan idiomatik.

Pengelolaan kelas dalam belajar mengajar bahasa Melayu dilakukan dengan cara meningkatkan hasil pembelajaran bahasa Melayu agar tercapai tujuan secara efektif, dan efisien. Evaluasi sebagai proses pelajaran dalam pembelajaran bahasa Melayu menggunakan tes berbahasa dari membaca, berbicara, menyimak dan menulis. Prosedur evaluasi penilaian yang digunakan tepat dan jelas. Alat evaluasi sudah sesuai dengan RPP dan kemampuan siswa yang berhubungan dengan aspek kognitif, sosial, afektif, dan personal. Alat pengukur ini sudah mencakup materi dan keterampilan siswa.

Saran

Berdasarkan pada kesimpulan dalam penelitian ini maka dapat dikemukakan beberapa saran untuk dapat dilakukan oleh berbagai pihak, yaitu: (1) Pada hasil penelitian di SD Amanasak dapat menggunakan atau menerapkan tiga metode pembelajaran . Kepada pihak sekolah disarankan untuk memperhatikan dalam menentukan kebijakan-kebijakan selanjutnya, perlu ditambahkan teori atau pendekatan/metode dalam bahasa target (The direct method) akan lebih bervariasi, efektif dan efisien. (2) Hasil penelitian ini sebagai bahan perbandingan dan pelajaran bagi guru bahasa Melayu. Disarankan kepada guru dan pihak sekolah lain yang perlu menggunakan proses pembelajaran bahasa Melayu dalam kelas akan dapat dilaksanakan. (3) Disarankan kepada gu- ru untuk menggunakan media dalam laboratorium bahasa antara lain: berupa CD/DVD player, komputer, audio visual, multimidia, tape recoder, kamus dengan lebih sering agar siswa menggunakan bahasa secara spontan dan membuat proses belajar berlangsung secara efisien dan lancar. (4) Disarankan kepada peneliti lain agar lebih memperhatikan segala keterbatasan dalam penelitian ini demi lebih optimalnya hasil penelitian lanjutan, misalnya dengan melibatkan aspek lain dan memperluas materi yang digunakan dalam penelitian, sehingga memungkinkan diperoleh hasil yang komprehensif.

\section{Daftar Pustaka}

Arends, R. I. (1997). Classroom instruction and management. New York: The McGraw-Hill Co, Inc.

Azhar, Rofa Yulia. (20 Juni 2012). Perbedaan model pembelajaran, pendekatan pembelajaran, strategi pembelajaran, metode pembelajaran dan teknik pembelajaran. Ensiklopedia Elektronik Indonesia. Diakses tanggal 18 Juni 2013 dari http://share-pangaweruh.blogspot.com/2012/06/perbedaan-modelpembelajaran-pendekatan.html.

Brown, H. D. (2001). Teaching by principles. An interactive approach to language pedagogy. Second edition. New York: AW Longman, Inc.

Chaer, Abdul. (2009). Psikolinguistik kajian teoretik. Edisi revisi. Jakarta: Rineka Cipta.

Christopher, J. (1995). Teaching strategies (Con't) enhancing student envolvement. Diakses tanggal 12 Juli 2012 dari http:/www.uky.edu/ugs/tlc/topik/teaching3/library/jurnal/vol2no2.

Djamarah, Syaiful Bahri. \& Zain, Aswan. (1997). Strategi belajar mengajar. Jakarta: Rineka Cipta.

(2010). Strategi belajar mengajar. Jakarta: Rineka Cipta.

Evertson, C. M. (1984). Classroom management for elementary teachers. Englewood Cliffs, New Jersey: PrenticeHall, Inc. 
Finocchioro, M. (1981). The second language classroom. New York: Oxford University.

Hamalik, Omar. (1994). Media pendidikan. Bandung: Citra Aditya Bakti. . (2011). Kurikulum dan pembelajaran. Jakarta: PT Bumi Aksara.

Hopkins, D. (1993). A teacher's guide to classroom research. Bristol: Open University Press.

Iskandarwassid \& Sunendar, Dadang. (2011). Strategi pembelajaran bahasa. Bandung: PT Remaja Rosdakarya Offset.

Jurasaite-Harbison, E. (2009). Teachers' workplace learning within informal contexts of school cultures in the United States and Lithuania. Hofstra University, New York, New York, USA. Journal of Workplace Learning. Vol. 21. No. 4. 299-321

Khine, S. M., et al. (2005). Classrom management: facilitating teaching and learning. Singapore: Pearson Education South Asia Pte Ltd.

Ilyas, Mahyudin. (13 Maret 2009).Pembelajaran dan penelitian bahasa Melayu di Thailand dan pemanfaatan TIK. Thaksin University, Songkhla, Thailand. Diakses tanggal 24 December 2011, dari

http://www.scribd.com/doc/13243287/Pembela jaran-dan-Kajian-Bahasa-Melayu.

Miarso,.Yusufhadi (2000). Media instruksional. Pusat TKPK. Jakarta: Departemen Pendidikan dan Kebudayaan.
Miles, M. B. \& Huberman, A. M. (2009). Qualitative data analisis: an expended sourcebook. Second edition. California: Sage Publications.

Oxford, L. R. (1990). Language learning strategies: what ever teacher should know. Massachusetts: A division of Wadsworth, Inc.

Richards, J. C. \& Rodgers, T. S. (1995). Approach and methods in language teaching: A description and analysis. USA: Cambridge University Press.

Sadiman, Arief S., et al. (2011). Media pendidikan: pengertian, pengembang-an, dan pemanfaatannya. Jakarta: Raja Grafindo Persada.

Sudjana, Nana \& Rivai, Ahmad. (1997) Media pengajaran. Bandung: Sinar Baru Algesindo.

Susarno, Lamijan Hadi. (2010). Strategi penyampaian bahan ajaran melalui pemanfaatan metode dan media dalam proses pembelajaran [Versi electronik]. Jurnal Teknologi Pendidikan, Vol. 10 No 1, April tahun 2010. Error! Hyperlink reference not valid.

Zulkifley, Hamid. (2006). Aplikasi psikolinguistik dalam pengajaran dan pembelajaran bahasa: siri pengajaran dan pembelajaran bahasa Melayu. Kualalumpur: PTS Professional Publishing. 